\title{
Increased Fat-Free Body Mass and No Adverse Effects on Blood Lipid Concentrations 4 Weeks after Additional Meat Consumption in Comparison with an Exclusion of Meat in the Diet of Young Healthy Women
}

\author{
Klaus J. Petzke, Susen Lemke, and Susanne Klaus \\ Group of Stable Isotopes and of Energy Metabolism, German Institute of Human Nutrition in Potsdam-Rehbruecke (DIfE), \\ Arthur-Scheunert-Allee 114-116, 14558 Nuthetal, Germany \\ Correspondence should be addressed to Klaus J. Petzke, petzke@dife.de
}

Received 14 September 2010; Revised 28 February 2011; Accepted 12 April 2011

Academic Editor: H. Boeing

Copyright ( 2011 Klaus J. Petzke et al. This is an open access article distributed under the Creative Commons Attribution License, which permits unrestricted use, distribution, and reproduction in any medium, provided the original work is properly cited.

\begin{abstract}
Aims. To investigate whether changes of meat consumption can affect body composition and laboratory parameters in healthy, normal weight, young women without the aim to reduce body weight. Research Design and Methods. Women volunteered to eat low-fat meat in addition to their habitual diet $(\mathrm{M})$ or to exclude meat products from their diet (NOM). After 4 weeks $\mathrm{M}$ and NOM were crossed over between subjects. Changes in nutrient intake, morphometrics and plasma parameters were compared during M and NOM. Results. Daily protein intake (means \pm SD) was $2.25 \pm 0.35(25.2 \%$ of energy) and $1.15 \pm 0.26 \mathrm{~g} / \mathrm{kg}(14.0 \%$ of energy) during M and NOM, respectively. Fat-free body mass (FFM) increased during $\mathrm{M}(0.7 \pm 1.0 \mathrm{~kg}, P=.02)$ and decreased during NOM $(-0.8 \pm 0.8 \mathrm{~kg}, P=.003)$. Body fat mass was unchanged. Concentrations of total cholesterol ( $-7 \%)$, LDL-cholesterol $(-8 \%)$, and glucose $(-4 \%)$ deceased significantly after M. Fasting glutamine concentrations were decreased by $\mathrm{M}$ and increased by NOM. Conclusions. Additional meat intake can increase FFM without adverse effects on blood lipid concentrations. Long-term studies are required. Urinary excretion of 3-methylhistidine could represent a biomarker for meat protein consumption.
\end{abstract}

\section{Introduction}

High-protein diets are suggested to increase satiety, to benefit fat oxidation, to reduce energy efficiency during overfeeding, and to contribute to a better conservation of fat-free body mass (FFM) which can support diet therapies of biomedical problems such as obesity or loss of FFM [14]. For the majority of the population, a practical means of increasing the intake of protein of high biological value is the introduction of lean meat into each meal [5]. Moreover, meat is one of the main animal protein sources of habitual diets in Germany ( $25 \%$ of total protein intake; median meat intake of $65 \mathrm{~g} / \mathrm{d}$ for 25-34 y old women) [6]. However, benefits and risks of high-protein and (or) high-red-meatcontaining diets are controversially discussed and there is a lack of information about long-term effects [7-9]. Recent epidemiological studies suggest that a high consumption of red meat may be linked with diabetes and some types of cancer [10-12]. In addition, Micha et al. [13] concluded in a systematic review and meta-analysis that processed meat, but not red meat, is associated with a higher incidence of cardiovascular diseases and diabetes mellitus. Nonetheless, the results of a recent large follow-up study indicate that meat consumption is positively related to weight gain in men and women and in normal-weight and in overweight subjects suggesting that after all a decrease in meat consumption may improve weight management [14]. In this sense, it is important to investigate the effects of changes in the consumption of meat in the etiology of different pathologies. In our study we aimed to compare the outcomes of an adaptation to an additional intake of meat with those of an omission of all meat products on selected anthropometric and laboratory parameters. Young, healthy, normal weight women who took part in this crossover study volunteered 
to eat low-fat meat (200 g lean pork fillet corresponding to $\sim 42 \mathrm{~g}$ protein) in addition to their habitual diet or to exclude all meat products from their diet for 4 weeks, respectively. Subjects were supposed not to reduce body weight for a better discrimination of possible effects of high-protein (-meat) intake from other metabolic effects due to weight reduction.

\section{Subjects and Methods}

2.1. Subjects and Study Design. Fourteen female subjects were recruited among students of the Institute of Nutritional Sciences at the University of Potsdam. Inclusion criteria were good health, age between 20 and 30 years old, a habitual protein intake of about $1 \mathrm{~g} / \mathrm{kg} / \mathrm{d}$, and no excessive intake of semiluxury food. Exclusion criteria were infectious, metabolic, and gastrointestinal diseases, food intolerances, eating disorders, pregnancy and lactation, extreme forms of dieting, and regular usage of drugs. After having received verbal and written information about the study, all subjects gave written consent. The study protocol was approved by the Ethics Committee of the University of Potsdam in accordance with the Helsinki declaration (decision 8/19 of November 18th, 2004).

The study had a randomized, crossover design, where 4 weeks of additional intake of exclusively low-fat pork fillet $(\mathrm{M})$ and an exclusion of meat and meat products (NOM) was examined, respectively. Baseline measurements were executed. After this seven of the subjects started the first dietary intervention period M (group A). Seven other subjects started with NOM (group B). After four weeks the interventions $\mathrm{M}$ and NOM were crossed over between subjects. During period M, participants were asked to eat the $200 \mathrm{~g}$ of lean pork fillet per day in addition to their usual diet. Pork fillet was bought by participants from local supermarkets and butcher's shops and costs were compensated. The origin of pork fillet was recorded. Participants were allowed to distribute the additional meat intake during $\mathrm{M}$ over the whole day. However, it was recommended not to be eaten together with the usual meals. This was done to ensure that the meat was eaten additionally to the habitual subjects' diet and that it was not used only for a replacement of their usual portions. Individual portions were reported in a protocol. During NOM participants were asked to abstain from consumption of all meat and meat products but were allowed to eat eggs and dairy products.

2.2. Data and Sample Collection. Dietary intake information was assessed by a semiquantitative and self-administered 4-d food record from Sunday to Wednesday prior to the study and during the fourth week of each intervention period [15]. The record was assigned by staff and subjects were instructed to record their entire food intake at the time of consumption. The food record as well as an accompanying data entry and nutrient calculation software program are available for download including a complete documentation of food coding (http://www.dife.de/). The coding of nutrient intake (including individual amino acids) was carried out on the basis of the German Food Code and Nutrient Data Base BLS II.3 (Federal Institute for Health and Protection of Consumers and Veterinary Medicine, 1999).

Subjects visited the institute between 0800 and $1000 \mathrm{~h}$ after an overnight fast at baseline and after 4 wks of each intervention period for anthropometric measurements and for sample collection. Blood samples were drawn into Li-heparinized tubes (Monovette, Sarstedt AG and Co., Nürnbrecht, Germany) which were placed on ice within $10 \mathrm{~min}$. Plasma was separated by centrifugation $(10 \mathrm{~min}$, $4^{\circ} \mathrm{C}, 2,000 \times \mathrm{g}$ ), frozen in liquid $\mathrm{N}_{2}$ within $30 \mathrm{~min}$ of blood collection, and stored at $-80^{\circ} \mathrm{C}$ before analysis. 24-hour collections of urine were made at baseline and within week 3 of each intervention period. Nitrogen excretion was measured in these samples.

\subsection{Anthropometrics, Body Composition, and Laboratory Pro-} cedures. Anthropometric measures were obtained by trained personnel while subjects wore no shoes and only light underwear. Body weight was assessed on an empty bladder using a digital scale to the nearest $100 \mathrm{~g}$ (Soehnle, Murrhardt, Germany). Body height was measured with a flexible anthropometer to the nearest $0.1 \mathrm{~cm}$ (Silber \& Hegner, Zürich, Switzerland). Body mass index (BMI) [weight (kg)/height ${ }^{2}$ $\left(\mathrm{m}^{2}\right)$ ] was calculated. Body fat mass and fat-free body mass (FFM) were measured by air displacement plethysmography (BodPod, Life Measurement, Inc., Concord, CA) according to the manufacturer's recommendations.

Concentrations of cholesterol, triacylglycerol, glucose, and insulin were measured using colorimetric or enzymatic standard methods. Nitrogen content of urine was determined using an elemental analyzer (intra-assay $\mathrm{CV}<3 \%$ ) (EA 1108, Fisons Instruments, Rodano, Italy). Amino acid and urea concentrations in plasma and urine were analyzed by ion-exchange chromatography as reported previously (intra-assay $\mathrm{CV}<5 \%$ ) [16]. The determination of total homocysteine (THC) was performed by GC-MS (intraassay CV $<5.5 \%$ ) (Varian Chromatography systems Walnut Creek, CA, coupled with SSQ 710, Thermo Finnigan, Bremen, Germany) on a DB-5MS column $(30 \mathrm{~m} \times 0.25 \mathrm{~mm}$ ID, $0.25 \mu \mathrm{m}$ film thickness; J\&W Scientific, Folsum CA) using DL- $\left[3,3,3^{\prime}, 3^{\prime}, 4,4,4^{\prime}, 4^{\prime}-\mathrm{D}_{8}\right]$ homocystine (98\%) (CIL, Andover, MA) as an internal standard [17].

2.4. Statistical Analyses. All data were tested for normal distribution with the Shapiro-Wilk test for normality. One value of FFM which was obviously an outlier possibly due to false data input was excluded from calculations. Descriptive analysis includes means \pm SD. Mean values are presented for baseline, M, and NOM $(n=14)$. The means after $\mathrm{M}$ and after NOM were tested for significant differences by dependent (paired samples) $t$-test. In addition, changes were calculated between subject-specific values after either $\mathrm{M}$ or NOM in relation to values before $\mathrm{M}$ or NOM, namely, baseline or end of first intervention period. The significance of the resulting effect of $\mathrm{M}$ or NOM calculated as change of individual values was computed using the 2tailed one sample $t$-test with zero as hypothetical mean value. 


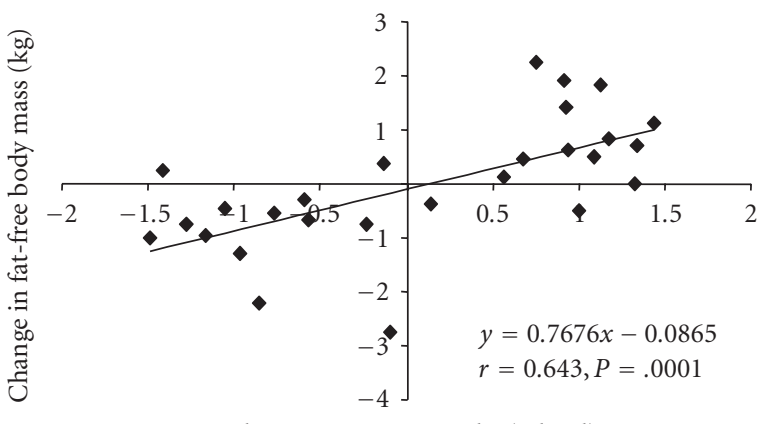

Change in protein intake $(\mathrm{g} / \mathrm{kg} / \mathrm{d})$

FIGURE 1: Combined plot showing the relationship between changes in protein intake and changes of fat-free body mass (FFM) of 14 young healthy women after consumption of diets for 4 wks containing either additional meat (M, 200 g pork fillet/d) or exclusion of all meat products (NOM). Individual differences have been computed for each of the 14 subjects after each 4 weeks period relative to previous period, namely, baseline or end of first intervention period. Calculations of protein intake were based on 4 -d food records. One value of FFM which was obviously an outlier was excluded.

TABle 1: Characteristics of women at baseline and after 4 weeks additional meat intake (M, $200 \mathrm{~g}$ pork fillet/d) or exclusion of meat products $(\mathrm{NOM}){ }^{1}$

\begin{tabular}{lcccc}
\hline & & Baseline & M & NOM \\
\hline Age & $(\mathrm{y})$ & $26.1 \pm 2.0$ & - & - \\
Weight & $(\mathrm{kg})$ & $60.4 \pm 5.5$ & $60.7 \pm 5.8^{\mathrm{b}}$ & $60.1 \pm 5.7^{\mathrm{a}}$ \\
Height & $(\mathrm{cm})$ & $167.4 \pm 6.3$ & - & - \\
BMI & $\left(\mathrm{kg} / \mathrm{m}^{2}\right)$ & $21.6 \pm 2.0$ & $21.7 \pm 2.0^{\mathrm{b}}$ & $21.5 \pm 2.0^{\mathrm{a}}$ \\
Body fat mass & $(\mathrm{kg})$ & $16.2 \pm 4.7$ & $16.2 \pm 5.0$ & $16.1 \pm 4.9$ \\
Fat-free body mass & $(\mathrm{kg})$ & $44.2 \pm 4.8$ & $44.5 \pm 4.5$ & $44.0 \pm 4.4$ \\
\hline
\end{tabular}

${ }^{1}$ Values are means $\pm \mathrm{SD}, n=14$. The values at baseline did not differ significantly between subjects starting intervention with either M or NOM. ${ }^{\mathrm{a}, \mathrm{b}}$ Within a row different superscripts indicate $P<.05$ between $\mathrm{M}$ and NOM (paired $t$-test).

The relationships between variables were estimated by Pearson correlations (anthropometric and biochemical data against dietary data). Regression analysis was used to evaluate the relationship between dietary data and measured data. Standardized regression coefficients were tested by $t$ test for deviation from the null hypothesis. The significance threshold was set at $P=.05$. We used SPSS for Windows (version 14.0.1, SPSS GmbH Software, Munich, Germany) or WinSTAT (version 1999.2, R. Fitch software, Staufen, Germany) for statistical evaluations.

\section{Results}

3.1. Subjects. Baseline characteristics of the subjects are presented in Table 1. The dietary interventions were well tolerated by all subjects. Biochemical values at baseline and after intervention periods were found to be within normal ranges (Table 3). The primary outcome measurements were not significantly different at baseline between 7 subjects starting first intervention period with either M or NOM.
3.2. Dietary Intervention. Dietary macronutrient and energy intake were reported in Table 2. At baseline the subjects' diets provided energy in the form of $17 \%$ protein, $32 \%$ fat, and $51 \%$ carbohydrate. Furthermore, throughout period M, the daily protein consumption was higher by 0.85 and $1.1 \mathrm{~g} / \mathrm{kg}$ as compared to baseline and NOM, respectively [18]. Throughout $\mathrm{M}$ and NOM subjects consumed $8 \%$ more and $3 \%$ less energy in the form of protein as compared to baseline, respectively. The changes in protein consumption were based on the modifications of meat protein intake. Consequently, the values of urinary urea and 3-methylhistidine $(3 \mathrm{MH})$ excretion were significantly higher during $M$ than during NOM (Table 3). The protein consumption was positively correlated with urinary urea and with $3 \mathrm{MH}$ excretion rate $\left(r=0.733, P=1.5 \times 10^{-8}\right.$ or $r=0.827, P=7.2 \times$ $10^{-12}$, resp.). Furthermore, an endogenous $3 \mathrm{MH}$ excretion of $\sim 90 \mu \mathrm{mol} / \mathrm{d}$ was computed relating the values of daily $3 \mathrm{MH}$ excretion of all participants against the animal protein intake at baseline, during $\mathrm{M}$ and during NOM based on 4-d food records $\left(y=0.0226 x^{2}+0.962 x+91.1, r=0.854\right)$.

The total fat consumption was significantly higher during $\mathrm{M}$ as compared to NOM. However, in terms of energy percentage, fat contribution was not significantly different. The total carbohydrate consumption was not significantly different between $\mathrm{M}$ and NOM. However, carbohydrates provided about $10 \%$ less energy throughout $\mathrm{M}$ as compared to NOM. The mean total energy intake was significantly higher during M by about $290 \mathrm{kcal} / \mathrm{d}$ compared to NOM.

3.3. Body Composition and Laboratory Measurements. The BMI was significantly higher after $\mathrm{M}$ compared to NOM (Table 1). The BMI increased during $\mathrm{M}\left(+0.24 \pm 0.30 \mathrm{~kg} / \mathrm{m}^{2}\right.$, $P=.027)$ and decreased during NOM $\left(-0.28 \pm 0.23 \mathrm{~kg} / \mathrm{m}^{2}\right.$, $\left.P<.1 \times 10^{-4}\right)$. However, the significant increase in body weight by about $0.7 \mathrm{~kg}$ during $\mathrm{M}(P=.02)$ and the decrease in body weight by about $0.8 \mathrm{~kg}$ during $\operatorname{NOM}\left(P=.7 \times 10^{-4}\right)$ was based exclusively on changes of FFM. In addition, there was a positive correlation of changes in total protein intake with changes in BMI $\left(r=0.704, P=.1 \times 10^{-5}\right)$ and FFM (Figure 1).

Interestingly, fasting concentrations of total cholesterol, LDL cholesterol, and glucose were not significantly different between $\mathrm{M}$ and NOM (Table 3). However, the means of individual changes were significantly lower $(P<.05)$ after M by $7 \%, 8 \%$, and $4 \%$, respectively (Table 4 ). Furthermore, the changes in total protein consumption during both $\mathrm{M}$ (increase) and NOM (decrease) were negatively correlated with individual changes in fasting concentrations of glucose $(r=-0.356, P=.031)$ and total cholesterol $(r=$ $-0.336, P=.04$ ) (data not shown). The fasting mean THC concentrations in plasma were also not significantly different between $\mathrm{M}$ and $\mathrm{NOM}$ and were $\sim 10 \mu \mathrm{mol} / \mathrm{L}$ (Table 3 ). As compared to baseline the mean THC concentrations were higher after both $\mathrm{M}$ and NOM by $\sim 3 \mu \mathrm{mol} / \mathrm{L}$ and the increases were significant $(P<.001$, Table 4$)$. There was no significant correlation between changes in total protein intake and changes of fasting THC concentrations $(r=0.217, P=.08)$. However, there revealed a negative correlation between changes in total protein intake during 
TABLE 2: Nutrient intakes of women at baseline and during 4 weeks periods of consuming diets with either additional meat content (M, $200 \mathrm{~g}$ pork fillet/d) or exclusion of meat products (NOM).

\begin{tabular}{lcccc}
\hline & & Baseline & M & NOM \\
\hline Total protein & $(\mathrm{g} / \mathrm{kg} \cdot \mathrm{d})$ & $1,40 \pm 0,29$ & $2,25 \pm 0,35^{\mathrm{b}}$ & $1,15 \pm 0,26^{\mathrm{a}}$ \\
& $(\mathrm{g} / \mathrm{d})$ & $84,1 \pm 16,0$ & $134,7 \pm 15,8^{\mathrm{b}}$ & $69,3 \pm 16,5^{\mathrm{a}}$ \\
& $(\%$ of energy intake) & $17.1 \pm 3.2$ & $25.2 \pm 3.0^{\mathrm{b}}$ & $14.0 \pm 3.4^{\mathrm{a}}$ \\
Leucine & $(\mathrm{g} / \mathrm{d})$ & $6.51 \pm 1.33$ & $9.86 \pm 1.32^{\mathrm{b}}$ & $5.44 \pm 1.32^{\mathrm{a}}$ \\
Methionine & $(\mathrm{g} / \mathrm{d})$ & $1.74 \pm 0.39$ & $2.99 \pm 0.36^{\mathrm{b}}$ & $3.32 \pm 0.34^{\mathrm{a}}$ \\
Vegetable protein & $(\mathrm{g} / \mathrm{d})$ & $29.7 \pm 5.9$ & $30.1 \pm 8.5$ & $32.1 \pm 6.4$ \\
Animal protein & $(\mathrm{g} / \mathrm{d})$ & $54.4 \pm 16.1$ & $104.5 \pm 15.3^{\mathrm{b}}$ & $37.1 \pm 12.7^{\mathrm{a}}$ \\
Fat & $(\mathrm{g} / \mathrm{d})$ & $71,9 \pm 13,1$ & $33.0 \pm 16,4^{\mathrm{b}}$ & 6.8 \\
& $(\%$ of energy intake $)$ & $32.4 \pm 5.9$ & $229,5 \pm 47,3$ & $33.2 \pm 6.8$ \\
Carbohydrates & $(\mathrm{g} / \mathrm{d})$ & $253,8 \pm 50,0$ & $42.0 \pm 8.8$ & $248,4 \pm 40,5$ \\
& $(\%$ of energy intake $)$ & $51.0 \pm 10.2$ & $2247 \pm 305^{\mathrm{b}}$ & $53.3 \pm 8.7$ \\
Energy & $(\mathrm{kcal} / \mathrm{d})$ & $2062 \pm 330$ & $1956 \pm 328^{\mathrm{a}}$ \\
\hline
\end{tabular}

${ }^{1}$ Values are means $\pm \mathrm{SD}, n=14$. The dietary intakes at baseline did not differ significantly between subjects starting intervention with either M or NOM.

a,b Within a row different superscripts indicate $P<.05$ between M and NOM (paired $t$-test).

TABLE 3: Plasma metabolite concentrations, urinary excretion of nitrogen, urea, and 3-methylhistidine of women at baseline and after 4 weeks periods of either additional meat consumption (M, $200 \mathrm{~g}$ pork fillet/d) or exclusion of meat products (NOM). ${ }^{1}$

\begin{tabular}{|c|c|c|c|c|}
\hline & & Baseline & $\mathrm{M}$ & NOM \\
\hline \multicolumn{5}{|l|}{ Plasma concentration } \\
\hline Urea & $(\mathrm{mmol} / \mathrm{L})$ & $3.96 \pm 1.22$ & $5.32 \pm 1.03^{\mathrm{b}}$ & $3.48 \pm 0.65^{\mathrm{a}}$ \\
\hline Total cholesterol & $(\mathrm{mmol} / \mathrm{L})$ & $4.86 \pm 0.93$ & $4.59 \pm 0.87$ & $4.84 \pm 0.81$ \\
\hline HDL-cholesterol & $(\mathrm{mmol} / \mathrm{L})$ & $1.65 \pm 0.24$ & $1.61 \pm 0.23$ & $1.62 \pm 0.21$ \\
\hline LDL-cholesterol & $(\mathrm{mmol} / \mathrm{L})$ & $2.75 \pm 0.75$ & $2.60 \pm 0.57$ & $2.72 \pm 0.6$ \\
\hline Triacylglycerol & $(\mathrm{mmol} / \mathrm{L})$ & $1.00 \pm 0.27$ & $0.84 \pm 0.23^{\mathrm{a}}$ & $1.10 \pm 0.35^{\mathrm{b}}$ \\
\hline NEFA & $(\mathrm{mmol} / \mathrm{L})$ & $0.36 \pm 0.17$ & $0.31 \pm 0.12$ & $0.35 \pm 0.18$ \\
\hline Glucose & $(\mathrm{mmol} / \mathrm{L})$ & $4.65 \pm 0.37$ & $4.46 \pm 0.31$ & $4.56 \pm 0.28$ \\
\hline Insulin & $(\mathrm{mU} / \mathrm{L})$ & $6.09 \pm 3.54$ & $6.17 \pm 2.7$ & $5.07 \pm 1.46$ \\
\hline Total homocysteine & $(\mu \mathrm{mol} / \mathrm{L})$ & $6.93 \pm 1.50$ & $9.77 \pm 2.75$ & $9.91 \pm 1.74$ \\
\hline 3-Methylhistidine & $(\mu \mathrm{mol} / \mathrm{L})$ & $3.20 \pm 0.70$ & $5.80 \pm 1.7^{\mathrm{b}}$ & $2.60 \pm 0.4^{\mathrm{a}}$ \\
\hline \multicolumn{5}{|l|}{ Urinary excretion } \\
\hline Nitrogen & $(\mathrm{g} / \mathrm{d})$ & $10.1 \pm 2.8$ & $15.9 \pm 3.7^{\mathrm{b}}$ & $8.8 \pm 2.2^{\mathrm{a}}$ \\
\hline Urea & $(\mathrm{mmol} / \mathrm{d})$ & $296 \pm 77$ & $440 \pm 105^{\mathrm{b}}$ & $248 \pm 74^{\mathrm{a}}$ \\
\hline 3-Methylhistidine & $(\mu \mathrm{mol} / \mathrm{d})$ & $229 \pm 93$ & $427 \pm 99^{\mathrm{b}}$ & $133 \pm 41^{\mathrm{a}}$ \\
\hline
\end{tabular}

${ }^{1}$ Values are means $\pm \mathrm{SD}, n=14$. The dietary intakes at baseline did not differ significantly between subjects starting intervention with either M or NOM. a,b Within a row different superscripts indicate $P<.05$ between M and NOM (paired $t$-test).

both $\mathrm{M}$ and $\mathrm{NOM}$ and individual changes in plasma glutamine concentrations $(r=-0.362, P<.03)$ or changes in glutamine to cystine ratios $(r=-0.518, P<.003)$ (data not shown) which was suggested to be a marker of skeletal muscle catabolic state [19]. This correlation was based predominantly on significant negative $(-41 \pm 74 \mu \mathrm{mol} / \mathrm{L})$ and positive $(+38 \pm 60 \mu \mathrm{mol} / \mathrm{L})$ individual changes of fasting glutamine concentrations after $\mathrm{M}$ and NOM, respectively. Nevertheless, the mean fasting concentrations of indispensable amino acids lysine and valine were significantly higher after M compared to NOM (Table 5).

\section{Discussion}

Previous studies on the health effects of high-protein diets were mostly performed within the context of weight loss diets in which it may be difficult to discriminate between metabolic effects due to weight loss or due to protein consumption by itself. Here we present the results of a study in healthy, normal-weight women without the aim to reduce body weight. The primary finding was that adverse effects were not detected on body composition, concentrations of blood lipids, insulin, glucose, and THC measured after a 4 weeks dietary intervention with additional meat intake as compared to an exclusion of meat products which considerably increases or decreases the habitual daily animal protein consumption, respectively. The results have shown that after 4 weeks additional meat consumption FFM was higher in young normal-weight woman without changes in body fat content. The stability of body fat content during $\mathrm{M}$ is remarkable as the energy intake is higher compared to NOM. 
TABLE 4: Changes of plasma metabolite concentrations and urinary excretion of urea and of 3-methylhistidine of women during 4 weeks periods of either additional meat consumption (M, $200 \mathrm{~g}$ pork fillet/d) or exclusion of meat products (NOM). ${ }^{1}$

\begin{tabular}{|c|c|c|c|}
\hline & & M & NOM \\
\hline \multicolumn{4}{|l|}{ Plasma concentration } \\
\hline Urea & $(\mathrm{mmol} / \mathrm{L})$ & $+1.59 \pm 1.16^{* * *}$ & $-1.41 \pm 1.23^{* * *}$ \\
\hline Total cholesterol & $(\mathrm{mmol} / \mathrm{L})$ & $-0.35 \pm 0.35^{* *}$ & $+0.14 \pm 0.64$ \\
\hline HDL-cholesterol & $(\mathrm{mmol} / \mathrm{L})$ & $-0.05 \pm 0.15$ & $0.00 \pm 0.17$ \\
\hline LDL-cholesterol & $(\mathrm{mmol} / \mathrm{L})$ & $-0.24 \pm 0.34^{*}$ & $-0.05 \pm 0.53$ \\
\hline Triacylglycerol & $(\mathrm{mmol} / \mathrm{L})$ & $-0.14 \pm 0.30$ & $+0.20 \pm 0.42$ \\
\hline NEFA & $(\mathrm{mmol} / \mathrm{L})$ & $-0.04 \pm 0.13$ & $0.00 \pm 0.16$ \\
\hline Glucose & $(\mathrm{mmol} / \mathrm{L})$ & $-0.25 \pm 0.34^{*}$ & $+0.12 \pm 0.36$ \\
\hline Insulin & $(\mathrm{mU} / \mathrm{L})$ & $-0.23 \pm 3.31$ & $-0.63 \pm 3.12$ \\
\hline Total homocysteine & $(\mu \mathrm{mol} / \mathrm{L})$ & $+1.43 \pm 1.23^{* * *}$ & $+2.29 \pm 2.03^{* * *}$ \\
\hline 3-Methylhistidine & $(\mu \mathrm{mol} / \mathrm{L})$ & $+3.00 \pm 1.70^{* * *}$ & $-2.20 \pm 2.00^{* * *}$ \\
\hline \multicolumn{4}{|l|}{ Urinary excretion } \\
\hline Urea & $(\mathrm{mmol} / \mathrm{d})$ & $+160 \pm 95^{* * *}$ & $-156 \pm 155^{* *}$ \\
\hline 3-Methylhistidine & $(\mu \mathrm{mol} / \mathrm{d})$ & $+274 \pm 109^{* * *}$ & $-234 \pm 147^{* * *}$ \\
\hline
\end{tabular}
differences from zero (no change) were indicated by ${ }^{* * *} P<.001,{ }^{*} P<.01,{ }^{*} P<.05$ ( 2 -tailed one sample $t$-test with zero as hypothetical mean value).

TABLE 5: Fasting plasma free amino acid concentrations of women at baseline and after 4 weeks periods of either additional meat consumption (M, $200 \mathrm{~g}$ pork fillet/d) or exclusion of meat products $(\mathrm{NOM}){ }^{1}$

\begin{tabular}{|c|c|c|c|}
\hline & Baseline & M & NOM \\
\hline \multicolumn{4}{|c|}{ Indispensable amino acids $(\mu \mathrm{mol} / \mathrm{L})$} \\
\hline Histidine & $94 \pm 10$ & $100 \pm 18$ & $98 \pm 12$ \\
\hline Isoleucine & $51 \pm 8$ & $53 \pm 8$ & $53 \pm 7$ \\
\hline Leucine & $112 \pm 18$ & $117 \pm 14$ & $119 \pm 13$ \\
\hline Lysine & $159 \pm 21$ & $186 \pm 34^{\mathrm{b}}$ & $155 \pm 22^{\mathrm{a}}$ \\
\hline Methionine & $24 \pm 2$ & $28 \pm 7$ & $28 \pm 3$ \\
\hline Phenylalanine & $52 \pm 8$ & $60 \pm 9$ & $56 \pm 9$ \\
\hline Threonine & $153 \pm 45$ & $163 \pm 50$ & $146 \pm 34$ \\
\hline Tryptophan & $48 \pm 8$ & $51 \pm 8$ & $51 \pm 6$ \\
\hline Valine & $199 \pm 39$ & $233 \pm 39^{\mathrm{b}}$ & $204 \pm 23^{\mathrm{a}}$ \\
\hline \multicolumn{4}{|c|}{ Dispensable amino acids $(\mu \mathrm{mol} / \mathrm{L})$} \\
\hline Alanine & $331 \pm 61$ & $371 \pm 95$ & $455 \pm 136$ \\
\hline Arginine & $73 \pm 20$ & $80 \pm 17$ & $77 \pm 14$ \\
\hline Asparagine & $56 \pm 6$ & $61 \pm 10$ & $61 \pm 7$ \\
\hline Cystine & $50 \pm 6$ & $53 \pm 7$ & $53 \pm 9$ \\
\hline Glutamine & $552 \pm 72$ & $531 \pm 63$ & $567 \pm 72$ \\
\hline Glutamic acid & $18 \pm 5$ & $20 \pm 7$ & $20 \pm 8$ \\
\hline Glycine & $195 \pm 62$ & $194 \pm 58$ & $228 \pm 77$ \\
\hline Proline & $159 \pm 41$ & $165 \pm 46$ & $185 \pm 40$ \\
\hline Serine & $96 \pm 15$ & $96 \pm 14$ & $104 \pm 17$ \\
\hline Tyrosine & $47 \pm 12$ & $57 \pm 15$ & $55 \pm 9$ \\
\hline
\end{tabular}

${ }^{1}$ Values are means $\pm \mathrm{SD}, n=14$. The dietary intakes at baseline did not differ significantly between subjects starting intervention with either M or NOM. a,b Within a row different superscripts indicate $P<.05$ between $\mathrm{M}$ and NOM (paired $t$-test).

This result may be explained by higher energy expenditure in addition to increased fat oxidation following consumption of high-protein meals $[20,21]$.
Although, there are still no standard definitions for highprotein diets [8] we propose that the daily protein intake of about $1.4 \mathrm{~g} / \mathrm{kg}$ body weight (17\% of energy) at baseline in our healthy female subjects may be defined as relatively high compared with $0.8 \mathrm{~g} / \mathrm{kg}$ as currently recommended in dietary allowances to exclude protein deficiency [18]. During M subjects consumed more than $2 \mathrm{~g} / \mathrm{kg} / \mathrm{d}$ of protein ( $25 \%$ of energy). During NOM the mean daily protein consumption declined to $1.15 \mathrm{~g} / \mathrm{kg}$ ( $14 \%$ of energy), but it was still higher than $0.8 \mathrm{~g} / \mathrm{kg}$. The modifications of protein intake during $\mathrm{M}$ or NOM were clearly achieved by increases of meat consumption or the exclusion of all meat products, respectively (Table 2). This was reflected in blood levels and in excretion rates of urea which confirmed the good compliance of our study group.

In addition, we could show that blood levels and excretion rates of $3 \mathrm{MH}$ may characterize the extent of meat consumption. $3 \mathrm{MH}$ is mainly a constituent of muscle and meat proteins. It is therefore possible to be used as a tool to measure muscle protein breakdown after consumption of meat-free diets because of its quantitative excretion in urine. The endogenous $3 \mathrm{MH}$ excretion rate of young woman was reported to be $\sim 100 \mu \mathrm{mol} / \mathrm{d}$ [22]. This corresponds with our results showing $\sim 90 \mu \mathrm{mol} / \mathrm{d}$ when the function between $3 \mathrm{MH}$ excretion and animal protein intake was extrapolated. An increase in meat intake was shown to raise the urinary $3 \mathrm{MH}$ excretion rate in a dose-dependent manner [23]. This is in line with our results showing raised $3 \mathrm{MH}$ excretion rates when the proportion of animal protein intake is higher which is based on changes in meat consumption. Thus, we assumed that the urinary $3 \mathrm{MH}$ excretion promises to be a reliable biomarker for meat intake provided that further validating studies are performed [24].

A better preservation of lean body mass during highprotein diets has been reported in studies aimed to reduce body weight. This result was primarily ascribed to higher 
rates of net protein synthesis, increased accretion of tissue protein, and restrained body protein breakdown [25-27]. Campbell et al. [28] reported greater gains in FFM and skeletal muscle mass in response to resistance training in older men consuming a meat-containing diet as compared with lacto-ovo vegetarian diet. In analogy, older women can better preserve their muscle mass introducing animal protein into their diet [29]. Tan et al. [30] have reported lower protein oxidation rates when meat-containing highprotein test meals were consumed compared with dairy or soy containing meals indicating protein sparing effects with meat. Finally, ingestion of lean beef servings were shown to increase all plasma concentrations of indispensable amino acids and the fractional skeletal muscle protein synthesis rates in healthy persons compared to premeal periods [5]. We did not measure parameters of protein turnover. However, based on the average increase of FFM of about $0.7 \mathrm{~kg}(\sim 0.14 \mathrm{~kg}$ protein) during $\mathrm{M}$ it can be calculated that additionally $\sim 4.5 \mathrm{~g}$ of protein were retained daily in our subjects. Therefore, we speculate that the additional consumption of lean meat as a source of high biological value protein (and other essential nutrients) can enhance FFM which may have consequences, for example, in alleviating biomedical problems of the metabolic syndrome.

There is an ongoing discussion about pathogenic roles of amino acids, for example, in the development of insulin resistance [7-9, 25]. We did not detect considerable differences in fasting plasma amino acid concentrations between $\mathrm{M}$ and NOM (Table 5) which indicates that amino acids even when high-protein diets such as $\mathrm{M}$ are consumed effectively can be disposed by postprandial catabolic processes. However, shortly after high-protein containing meals postprandial amino acid concentrations may rise substantially. This may induce an increase in protein balance and, therefore, can enhance FFM after long-term exposures [26, 31]. However, we find it noteworthy, that the fasting glutamine concentrations in plasma were lower with increasing protein intake which may have long-term consequences as this amino acid has important metabolic functions not only as a substrate for protein synthesis. In analogy, decreased glutamine concentrations were detected after intakes of more than $2 \mathrm{~g}$ protein $/ \mathrm{kg} / \mathrm{d}$ as well as in catabolic patients $[19,32$, 33]. Interestingly, strong negative correlations were reported between body fat content and glutamine/cystine ratios of healthy persons [19] which corresponds with data of our subjects $(r=-0.517, P<.0003)$. Although, the biological or metabolic significance of this effect cannot be explained sufficiently it has been reported that catabolic conditions may result in lower plasma concentrations of glutamine or glutamine/cystine ratios $[19,32]$.

Finally, we detected similar THC as well as methionine concentrations 4 weeks after exposure to either M or NOM. Methionine is known as the sole precursor of THC. However, the calculated methionine intake has been considerably lower during NOM as compared to M (Table 2). The results agree with those showing that a high-methionine high-protein diet through increasing lean meat consumption in overweight subjects does not raise THC concentrations as compared with low-methionine low-protein diets after 6 months [34].
Therefore, the results may indicate no increasing risk of $\mathrm{M}$ compared to NOM for cardiovascular diseases based on THC as it have been shown for other unbalanced diets [35].

Limitations to our research include the fact that meat is not only a source of dietary protein. Among other nutrients it was proposed that iron derived from red meat may increase iron stores and consequently, could initiate oxidative damage and inflammation. This was suggested to be responsible for long-term adverse effects resulting in coronary heart disease and type 2 diabetes. However, a replacement of dietary carbohydrate with protein from red meat by an addition of lean red meat of approximately $215 \mathrm{~g} / \mathrm{d}$ was not shown to elevate several parameters responsible for oxidative stress and inflammation after an exposure of 8 weeks [36]. In addition, high-meat intake can be associated with higher saturated fat intake. Therefore, it was not surprising that we computed significantly higher-fat and -energy intakes during M compared to NOM. However, we find it meaningful that these modifications did not increase the body fat content and blood lipid parameters during $\mathrm{M}$ compared to NOM. Furthermore, it is not possible to generalize our results because we recruited only young healthy women for this study and one cannot exclude effects of sex and age as well. Nonetheless, our results and conclusions of this study are limited to the short-term because subjects were exposed only for 4 weeks. Long-term studies are required to define specific mechanisms and to explain the benefits or risks of high-meat intakes.

In summary, a 4 weeks exposure to $200 \mathrm{~g}$ lean meat added to the habitual diet of healthy young woman resulting in high-protein intakes seems not to produce adverse effects on body composition, concentrations of blood lipids, insulin, glucose, and THC compared with an exclusion of all meat products. The additional meat consumption may be effective in enhancing FFM with no change in fat mass. The urinary $3 \mathrm{MH}$ excretion may serve as a reliably biomarker for the consumption of meat protein provided that the validity was assessed in further studies. Further research is needed to assess the specific mechanisms that explain the possible benefits or risks of long-term high-protein (meat) consumption for nutrition-dependent diseases.

\section{Abbreviations}

3MH: 3-methylhistidine

BMI: Body mass index

FFM: Fat-free body mass

M: $\quad 4$ weeks period of habitual diet with additional $200 \mathrm{~g}$ pork fillet per $\mathrm{d}$

NEFA: Nonesterified fatty acids

NOM: 4 weeks period of habitual diet with exclusion of meat products

THC: Total homocysteine.

\section{Acknowledgments}

The study was supported in part by a Grant Pe643/6-1 from the Deutsche Forschungsgemeinschaft, Bonn, Germany. S. Klaus is a member of EU COST action MITOFOOD (COST 
FA 0602). The authors thank the subjects volunteering for these studies. Petra Albrecht, Katrin Sprengel, Katja Treu, and Andreas Wagner are gratefully acknowledged for excellent technical assistance, blood sampling, and for anthropometric evaluations.

\section{References}

[1] A. Adam-Perrot, P. Clifton, and F. Brouns, "Low-carbohydrate diets: nutritional and physiological aspects," Obesity Reviews, vol. 7, no. 1, pp. 49-58, 2006.

[2] M. S. Westerterp-Plantenga, N. Luscombe-Marsh, M. P. G. M. Lejeune et al., "Dietary protein, metabolism, and body-weight regulation: dose-response effects," International Journal of Obesity, vol. 30, no. 3, pp. S16-S23, 2006.

[3] D. K. Layman, E. M. Evans, D. Erickson et al., "A moderateprotein diet produces sustained weight loss and long-term changes in body composition and blood lipids in obese adults," Journal of Nutrition, vol. 139, no. 3, pp. 514-521, 2009.

[4] M. Batterham, R. Cavanagh, A. Jenkins, L. Tapsell, G. Plasqui, and P. Clifton, "High-protein meals may benefit fat oxidation and energy expenditure in individuals with higher body fat," Nutrition and Dietetics, vol. 65, no. 4, pp. 246-252, 2008.

[5] T. B. Symons, S. E. Schutzler, T. L. Cocke, D. L. Chinkes, R. R. Wolfe, and D. Paddon-Jones, "Aging does not impair the anabolic response to a protein-rich meal," American Journal of Clinical Nutrition, vol. 86, no. 2, pp. 451-456, 2007.

[6] G. Mensink, M. Burger, R. Beitz et al., Contributions to the Health Report Refund of the Federation. What Do We Eat Today? Diet Behavior in Germany, Robert Koch Institute, Berlin, Germany, 2002.

[7] C. C. Metges and C. A. Barth, "Metabolic consequences of a high dietary-protein intake in adulthood: assessment of the available evidence," Journal of Nutrition, vol. 130, no. 4, pp. 886-889, 2000.

[8] J. Eisenstein, S. B. Roberts, G. Dallal, and E. Saltzman, "Highprotein weight-loss diets: are they safe and do they work? A review of the experimental and epidemiologic data," Nutrition Reviews, vol. 60, no. 7, part 1, pp. 189-200, 2002.

[9] F. Tremblay, C. Lavigne, H. Jacques, and A. Marette, "Role of dietary proteins and amino acids in the pathogenesis of insulin resistance," Annual Review of Nutrition, vol. 27, pp. 293-310, 2007.

[10] M. B. Schulze, K. Hoffmann, H. Boeing et al., "An accurate risk score based on anthropometric, dietary, and lifestyle factors to predict the development of type 2 diabetes," Diabetes Care, vol. 30, no. 3, pp. 510-515, 2007.

[11] T. Norat, S. Bingham, P. Ferrari et al., "Meat, fish, and colorectal cancer risk: the European prospective investigation into cancer and nutrition," Journal of the National Cancer Institute, vol. 97, no. 12, pp. 906-916, 2005.

[12] J. M. Genkinger and A. Koushik, "Meat consumption and cancer risk," PLoS Medicine, vol. 4, no. 12, pp. 1883-1886, 2007.

[13] R. Micha, S. K. Wallace, and D. Mozaffarian, "Red and processed meat consumption and risk of incidenct coronary heart disease, stroke, and diabetes mellitus: a systematic review and meta-analysis," Circulation, vol. 121, no. 21, pp. 2271$2283,2010$.

[14] A. C. Vergnaud, T. Norat, D. Romaguera et al., "Meat consumption and prospective weight change in participants of the EPIC-PANACEA study," American Journal of Clinical Nutrition, vol. 92, pp. 398-407, 2010.
[15] C. Koebnick, K. Wagner, F. Thielecke et al., "An easy-to-use semiquantitative food record validated for energy intake by using doubly labelled water technique," European Journal of Clinical Nutrition, vol. 59, no. 9, pp. 989-995, 2005.

[16] K. J. Petzke, J. Proll, A. Elsner, F. Thielecke, and C. C. Metges, "Long-term high protein intake does not increase oxidative stress in rats," Journal of Nutrition, vol. 130, no. 12, pp. 28892896, 2000.

[17] S. P. Stabler, J. Lindenbaum, D. G. Savage, and R. H. Allen, "Elevation of serum cystathionine levels in patients with cobalamin and folate deficiency," Blood, vol. 81, no. 12, pp. 3404-3413, 1993.

[18] German Nutrition Society, Reference Values for Nutrient Intake (Deutsche Gesellschaft für Ernährung e. V., DGE, Referenzwerte für die Nährstoffzufuhr), Neuer Umschau Buchverlag, Neustadt an der Weinstraße, Germany, 2008.

[19] V. Hack, D. Schmid, R. Breitkreutz et al., "Cystine levels, cystine flux, and protein catabolism in cancer cachexia, HIV/SIV infection, and senescence," FASEB Journal, vol. 11, no. 1, pp. 84-92, 1997.

[20] T. L. Halton and F. B. Hu, "The effects of high protein diets on thermogenesis, satiety and weight loss: a critical review," Journal of the American College of Nutrition, vol. 23, no. 5, pp. 373-385, 2004.

[21] I. Labayen, N. Díez, D. Parra, A. González, and J. A. Martínez, "Basal and postprandial substrate oxidation rates in obese women receiving two test meals with different protein content," Clinical Nutrition, vol. 23, no. 4, pp. 571-578, 2004.

[22] H. N. Munro and V. R. Young, "Urinary excretion of $\mathrm{N}^{\mathrm{T}}$ methylhistidine (3-methylhistidine): a tool to study metabolic responses in relation to nutrient and hormonal status in health and disease of man," American Journal of Clinical Nutrition, vol. 31, no. 9, pp. 1608-1614, 1978.

[23] G. Huszar, G. Golenwsky, J. Maiocco, and E. Davis, "Urinary 3-methylhistidine excretion in man: the role of protein-bound and soluble 3-methylhistidine," British Journal of Nutrition, vol. 49, no. 3, pp. 287-294, 1983.

[24] S. A. Bingham, "Biomarkers in nutritional epidemiology," Public Health Nutrition, vol. 5, no. 6A, pp. 821-827, 2002.

[25] E. Farnsworth, N. D. Luscombe, M. Noakes, G. Wittert, E. Argyiou, and P. M. Clifton, "Effect of a high-protein, energyrestricted diet on body composition, glycemic control, and lipid concentrations in overweight and obese hyperinsulinemic men and women," American Journal of Clinical Nutrition, vol. 78, no. 1, pp. 31-39, 2003.

[26] D. K. Layman and D. A. Walker, "Potential importance of leucine in treatment of obesity and the metabolic syndrome," Journal of Nutrition, vol. 136, pp. 319S-323S, 2006.

[27] M. P. Harber, S. Schenk, A. L. Barkan, and J. F. Horowitz, "Effects of dietary carbohydrate restriction with high protein intake on protein metabolism and the somatotropic axis," Journal of Clinical Endocrinology and Metabolism, vol. 90, no. 9, pp. 5175-5181, 2005.

[28] W. W. Campbell, M. L. Barton Jr., D. Cyr-Campbell et al., "Effects of an omnivorous diet compared with a lactoovovegetarian diet on resistance-training-induced changes in body composition and skeletal muscle in older men," American Journal of Clinical Nutrition, vol. 70, no. 6, pp. 1032-1039, 1999.

[29] C. Lord, J. P. Chaput, M. Aubertin-Leheudre, M. Labonté, and I. J. Dionne, "Dietary animal protein intake: association with muscle mass index in older women," Journal of Nutrition, Health and Aging, vol. 11, no. 5, pp. 383-387, 2007. 
[30] S. Y. Tan, M. Batterham, and L. Tapsell, "Energy expenditure does not differ, but protein oxidation rates appear lower in meals containing predominantly meat versus soy sources of protein," Obesity Facts, vol. 3, no. 2, pp. 101-104, 2010.

[31] M. Balage and D. Dardevet, "Long-term effects of leucine supplementation on body composition," Current Opinion in Clinical Nutrition and Metabolic Care, vol. 13, no. 3, pp. 265270,2010

[32] A. H. Forslund, L. Hambræus, H. Van Beurden et al., "Inverse relationship between protein intake and plasma free amino acids in healthy men at physical exercise," American Journal of Physiology - Endocrinology and Metabolism, vol. 278, no. 5, pp. E857-E867, 2000.

[33] R. F. Grimble, "Nutritional modulation of immune function," Proceedings of the Nutrition Society, vol. 60, no. 3, pp. 389-397, 2001.

[34] N. Haulrik, S. Toubro, J. Dyerberg, S. Stender, A. R. Skov, and A. Astrup, "Effect of protein and methionine intakes on plasma homocysteine concentrations: a 6-mo randomized controlled trial in overweight subjects," American Journal of Clinical Nutrition, vol. 76, no. 6, pp. 1202-1206, 2002.

[35] P. Verhoef, "Homocysteine-an indicator of a healthy diet?" American Journal of Clinical Nutrition, vol. 85, no. 6, pp. 14461447, 2007.

[36] J. M. Hodgson, N. C. Ward, V. Burke, L. J. Beilin, and I. B. Puddey, "Increased lean red meat intake does not elevate markers of oxidative stress and inflammation in humans," Journal of Nutrition, vol. 137, no. 2, pp. 363-367, 2007. 


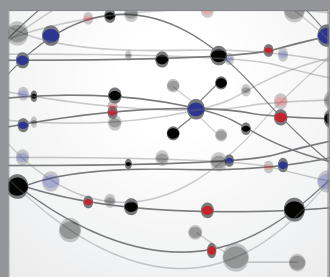

The Scientific World Journal
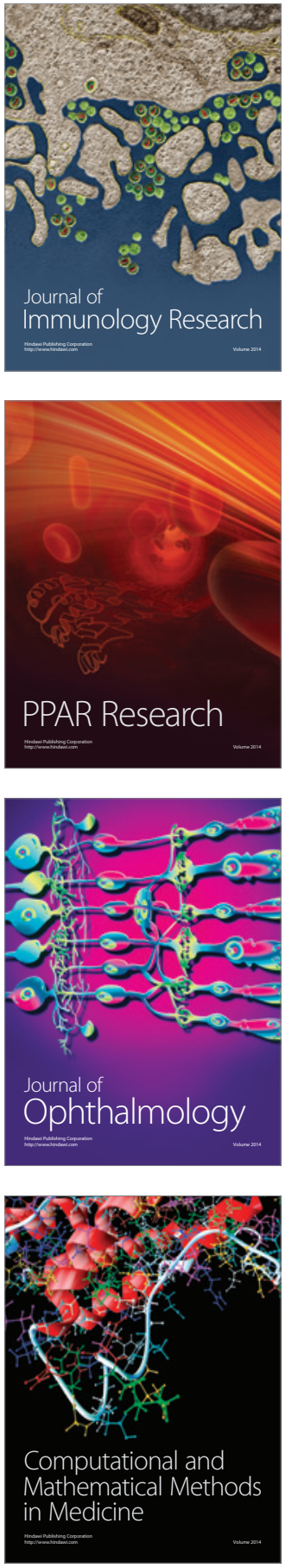

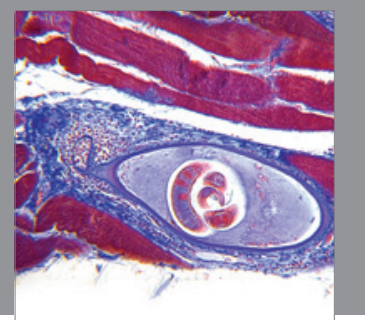

Gastroenterology

Research and Practice
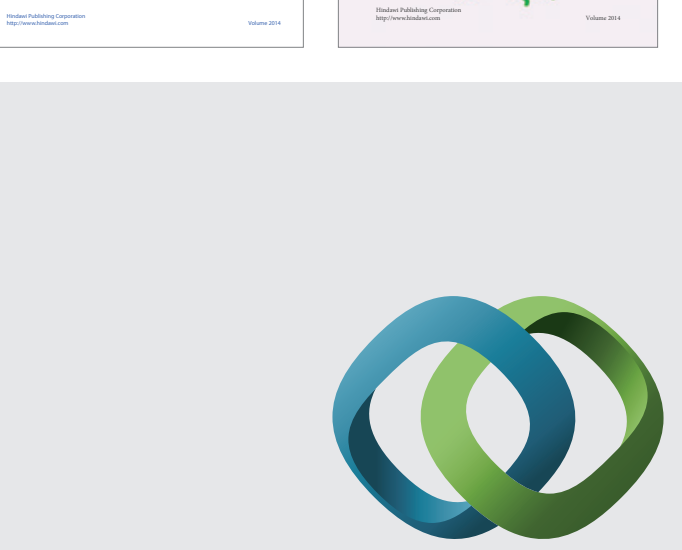

\section{Hindawi}

Submit your manuscripts at

http://www.hindawi.com
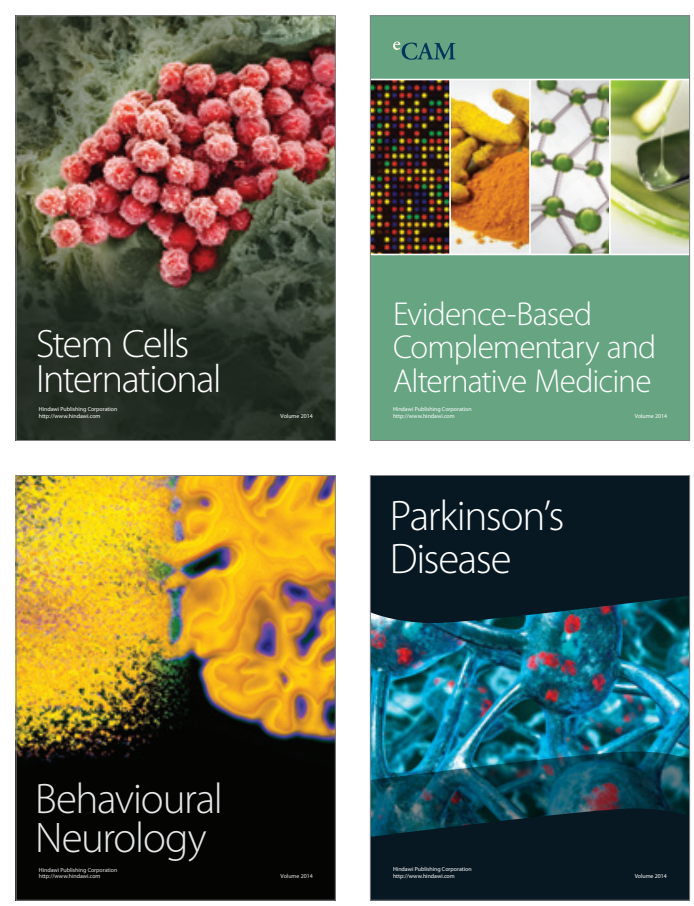

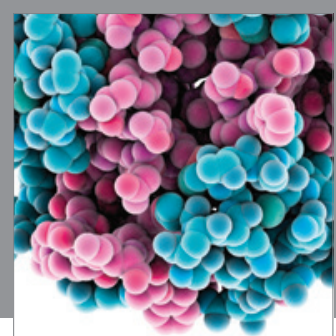

Journal of
Diabetes Research

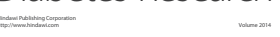

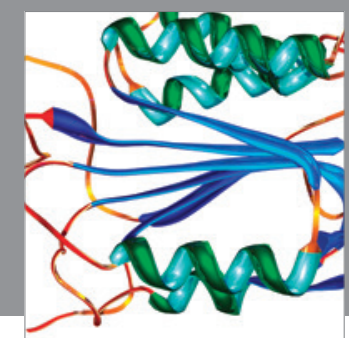

Disease Markers
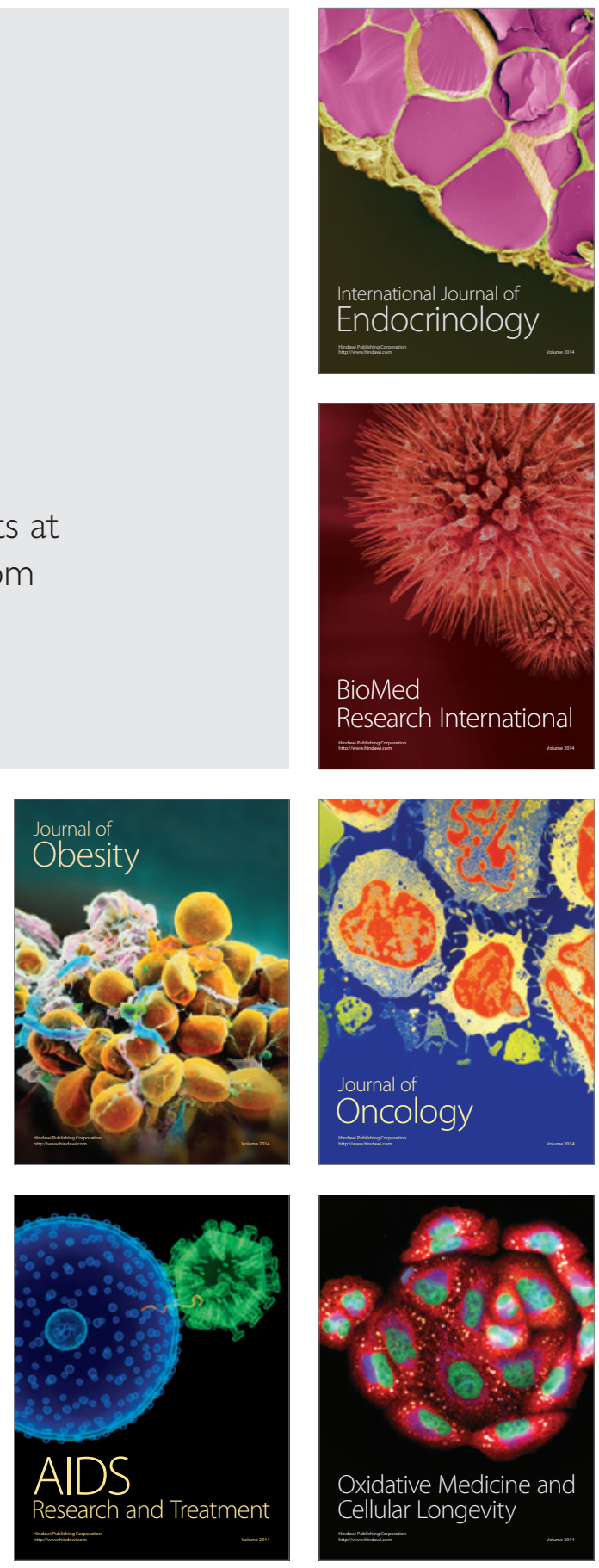